\title{
Leaf angle and leaf stomata responses to experimental drought in Quercus velutina and Acer saccharum
}

\author{
Brittany Nichole Casey \\ West Virginia University, bnc0015@mix.wvu.edu
}

Follow this and additional works at: https://researchrepository.wvu.edu/etd

Part of the Forest Biology Commons, Hydrology Commons, Other Ecology and Evolutionary Biology Commons, and the Other Environmental Sciences Commons

\section{Recommended Citation}

Casey, Brittany Nichole, "Leaf angle and leaf stomata responses to experimental drought in Quercus velutina and Acer saccharum" (2020). Graduate Theses, Dissertations, and Problem Reports. 7558. https://researchrepository.wvu.edu/etd/7558

This Thesis is protected by copyright and/or related rights. It has been brought to you by the The Research Repository @ WVU with permission from the rights-holder(s). You are free to use this Thesis in any way that is permitted by the copyright and related rights legislation that applies to your use. For other uses you must obtain permission from the rights-holder(s) directly, unless additional rights are indicated by a Creative Commons license in the record and/ or on the work itself. This Thesis has been accepted for inclusion in WVU Graduate Theses, Dissertations, and Problem Reports collection by an authorized administrator of The Research Repository @ WVU. For more information, please contact researchrepository@mail.wvu.edu. 
Leaf angle and leaf stomata responses to experimental drought in Quercus velutina and Acer saccharum

Brittany Nichole Casey

Thesis submitted to the

Eberly College of Arts and Sciences

at West Virginia University

in partial fulfillment of the requirements for the degree of

\title{
Master of Arts
}

In

\section{Geography}

Brenden E. McNeil, Ph.D., Chair

Nicolas Zegre, Ph.D.

Trevor Harris, Ph.D.

\section{Department of Geology and Geography}

\author{
Morgantown, West Virginia
}

2020

Keywords: forest ecology, ecosystem ecology, drought, drought response, throughfall exclusion experiment, crown architecture 


\begin{abstract}
Leaf angle and leaf stomata responses to experimental drought in Quercus velutina and Acer saccharum
\end{abstract}

\title{
Brittany Nichole Casey
}

The possibility of increased severity and frequency of drought conditions, as a result of global climate variability, greatly complicates our ability to forecast future forest functions such as productivity and carbon sequestration. Assessing how tree species vary in their response to drought can aid in predicting the impact on forest ecosystems as a whole. Throughfall exclusion (TfE) experiments are potentially useful tools to simulate realistic drought conditions within intact forest ecosystems. We employed a TfE experiment during the 2018 growing season within the WV Land Trust's Elizabeth's Woods Nature Preserve, near Morgantown, WV, to assess the leaf angle and leaf stomata responses of Quercus velutina and Acer saccharum trees to changes in water availability. I mounted time-lapse cameras within the forest crown of four experimental plots to track changes in leaf angle throughout the growing season. At the peak of the driest period of the summer, I also collected leaf samples for foliar isotopic concentrations analysis of leaf carbon $(\delta 13 \mathrm{C})$.

We consistently measured more vertical leaf angles within the $Q$. velutina plots compared to the A. saccharum plots. We found significantly more vertical mean leaf angles in the $Q$. velutina TfE treatment plot relative to the control plot at the beginning of the growing season, as soil moisture content declined, the vertical angles recorded in the control plot also increased. The $\delta 13 \mathrm{C}$ analysis did not show a significant difference between $Q$. velutina treatment and control, suggesting an absence of stomatal control. A. saccharum had significantly higher values of $\delta 13 \mathrm{C}$ in the treatment plot at the peak of the drought experiment, compared to the control and did not appear to adjust their leaf angle to account for the reduced water supply.

The leaf angle and leaf stomatal responses of these species are consistent with responses of other root and stem traits describing the position of each species on a theorized spectrum of hydrisity. In particular, the finding that anisohydric species use a mechanism of increasing leaf angle in response to low water availability has great implications for linking to remote sensing measurements and forecasts of forest functioning under the increasingly variable climatic conditions caused by global change. 
I dedicated this manuscript to my wonderful and supportive family and friends. Thank you for pushing me through to the end. Also, to Peter Albert, for teaching me, it is all in the attitude. You are so loved and very missed. 


\section{ACKNOWLEDGMENTS}

A special thank you to the many people who have supported and guided me through this process, my academic advisor: Brenden McNeil; my committee members: Nico Zegre and Trevor Harris, as well as Eungul Lee; collaborating professors and colleagues: Dr. Edward Brzostek, Dr. Rodrigo Fernandez, Nannette Raczka, Luis Andres Guillen, and Dr. Rick Landenberg; my funding sources: NASA WVSGC and WVU; the arborists who aided in placing and retrieving my equipment: Rob Eckendrode and Derek Buckel; the undergraduate researchers who assisted in analyzing my data; Danielle Canning and Molly Sherlock; and all those who provided encouraging words and emotional support for me throughout this experience, including my friends and family, especially Michelle Bester, Fang, Darren Gross, and Amber Williams. 


\section{Table of Contents}

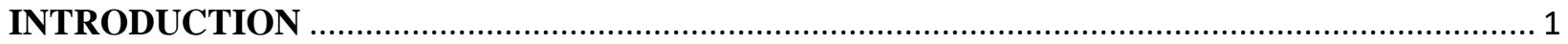

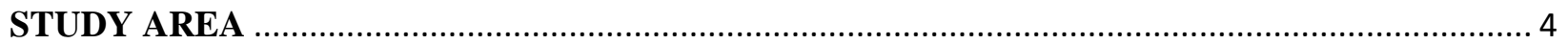

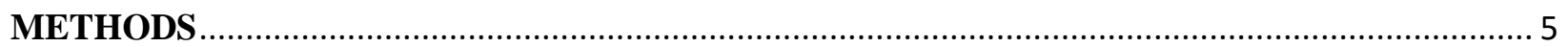

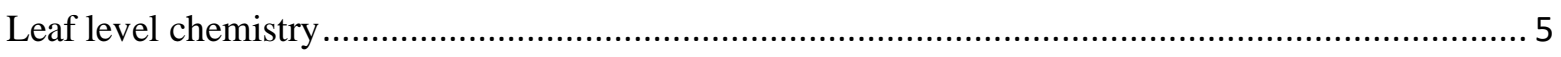

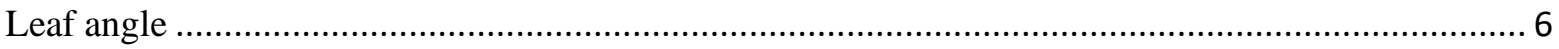

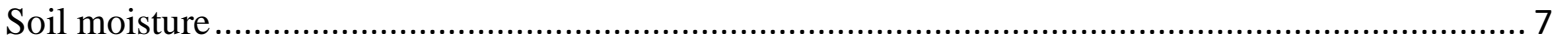

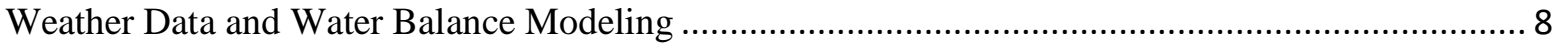

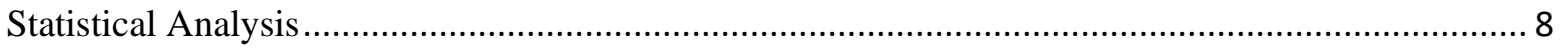

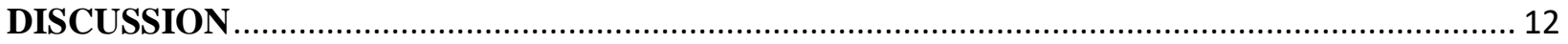

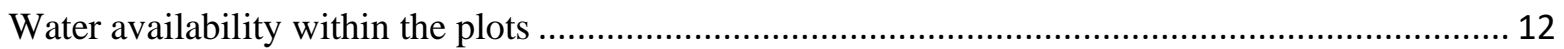

Leaf angle vs. Stomatal responses to reduced water availability .............................................. 14

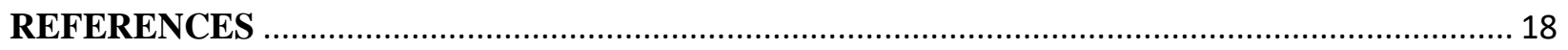

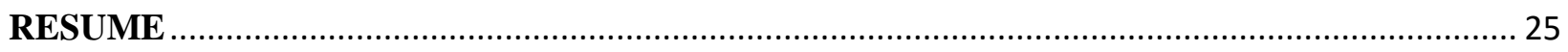

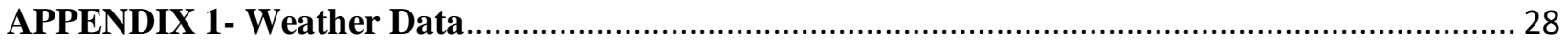

APPENDIX 2- Solar radiation modeling for Water balance ..................................................... 30

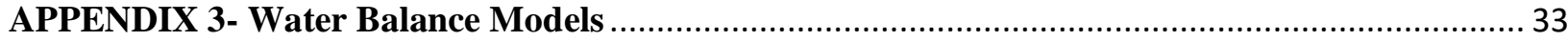

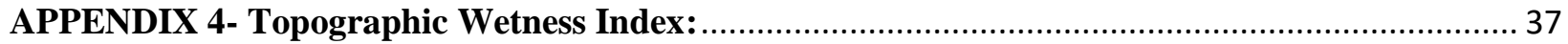




\section{LIST OF FIGURES}

1. Map of the Elizabeth's Woods Study Area

2. Example of imagery captured from time-lapse cameras, as well as leaf selection and measurement technique

3. Throughfall exclusion gutters at the Elizabeth Wood's Nature Preserve

4. Graphed results of field collection methods- GIS water balance model over precipitation, foliar isotopic analysis, leaf angle, and percent soil moisture

5. The relation between soil moisture and leaf angle by plot and species

6. Results of the multiple regression analysis of soil moisture, species, and treatment effect on leaf angle

\section{APPENDICES}

1. Weather station data

2. Solar radiation modeling for Water balance

3. Water Balance Model

4. Topographic Wetness Index 


\section{INTRODUCTION}

Ground-based observational data, satellites, and climate models are identifying rising atmospheric temperatures, increased instances of extreme weather events, and altered precipitation patterns across the globe (Walther et al., 2002; Mann et al., 2017). Precipitation patterns are impacted in a multitude of ways, including extended periods without water, and by reduced ability to capture water for storage during precipitation events due to the increased intensity of storms (Ryan, 2011). These climatic changes in available water to forests are now affecting forest functioning and the valuable ecosystem services linked to those functions, such as carbon sequestration, forest products, and the provision of water quality and quantity, as well as impacting global and local climate regulation (Oki, T. and Kanae, S., 2006; St. Clair, et al., 2008). Through effects on soil-root and leaf-atmosphere relationships, water availability strongly affects the productivity, growth, and health of forests across the world (Kirchen et al., 2017; Goisser et al., 2013; Baker et al., 2002; Knutzen et al., 2015).

Species-specific adaptations to water availability are theorized to vary along a spectrum of anisohydric vs. isohydric water management strategies (Chaves, 1991; Tardier and Simoneau, 1997). These whole-tree strategies have been fairly well described in terms traits measured on roots (Rodrigues et al., 1995; Chaves et al., 2002; Kozlowski and Pallardy, 2002), stems (Sharp and Davies, 1989; Gu et al., 2015), individual leaves (i.e., the shape, density, and size of leaves, and thickness of leaves, Turner, 1994), and the number and density of stomata (Lawson and Blatt, 2014).

Variations in traits correspond with the hydrisity strategy of a species. Regulating stomal conductance has been shown to affect water use efficiency in plants by allowing them to adjust transpiration and photosynthetic rates in response to water availability (Centritto et al. 2009). 
When facing water shortages, isohydric trees are thought to limit water loss through transpiration primarily by reducing stomatal conductance. This stomatal closure allows the trees to maintain a constant leaf water potential at the cost of productivity (Breda et al., 2006). On the other hand, anisohydric species, at the other end of the spectrum, are thought to keep stomata open, even in the face of decreased leaf water potential (Sade et al., 2012). Foliar isotopic concentration analysis can be used to assess stomatal conductance and serve as an indicator of drought stress (Cernusak et al., 2003). Specifically, carbon isotopic discrimination, $\delta 13 \mathrm{C}$, has been found to be a useful proxy for gas exchange in numerous studies. When stomata are open, the trees will more readily use the lighter $12 \mathrm{C}$ isotope, which reacts more quickly with the enzyme responsible for carbon fixation, resulting in a lower $\delta 13 C$ (Farquhar et al., 1982; Farquhar et al., 1989).

To combat the risk of maintaining open stomata, anisohydric species have developed other responses to water availability. Water availability is known to affect the architecture of tree crowns through traits known to affect intra-crown shading and evapotranspiration, such as leaf density, the vertical distribution of leaves, and the mean inclination angle of leaves in the tree crown (Ehleringer and Werk, 1986; Ellsworth and Reich, 1993; Castro and Fetcher, 1998; Lambers et al., 1998; Falster and Westoby, 2003). Yet, despite their known importance, the adaptive significance of this suite of crown architectural traits are less well understood than more easily measured leaf-level responses. The inclination angle of leaves, or leaf angle, is one crucial crown architectural trait that impacts light gradients within forest ecosystems, overall plant photosynthetic rates and productivity, water use, and leaf area index (Normal and Campbell 1989; Niinemets, 2010; Fotis and Curtis, 2016; Itakura and Hosoi, 2019). Studies have also tied increasingly vertical leaf angle to water availability (Givnish, 1984; Nagasuga et al., 2013). The 
technique, and degree to which the trees implement that technique, are also dependent on species-specific adaptations.

Thus, quantifying how individual species respond to reduced water availability can lead to a better understanding of the impact drought can have on forest ecosystems, and thereby improve their utility in forecasting forest functioning under the drought conditions that may come with global change. Moreover, these same crown architectural traits also have strong effects on forest spectral reflectance (Gates and Tantraporn, 1952; Gates et al., 1965; Knipling, 1970), creating a unique opportunity to use remote sensing to make broad-scale assessments of species differences in water management. Understanding tree species-specific response to changes in water availability on a broader level will aid in predictions of whole-scale forest response to climate change and inform better management practices.

Leveraging measurements within a throughfall exclusion (TfE) experiment, my study seeks to identify how two tree species use mechanisms of adjusting leaf angle and closing stomata as part of their responses to experimentally altered water availability. With this goal and objectives in mind, my study addressed the following hypotheses:

I. The isohydric species of Acer saccharum will have more horizontal leaf angles. A. saccharum will not adjust leaf angle throughout the growing season or in the TfE treatment plot, but rather will close stomata to reduce water loss.

II. The anisohydric species of Quercus velutina will have more vertical leaf angles throughout the TfE experiment and will have increasingly vertical leaf angles during periods of low water availability, especially in the TfE treatment plots. $Q$. velutina will not close stomata to reduce water loss. 


\section{STUDY AREA}

I conducted my research with the West Virginia Land Trust's Elizabeth's Woods (EW)

Nature Preserve located south of Morgantown, WV. The site encompasses 84 acres of forest containing 120+ year-old black oak (Quercus velutina) and sugar maple (Acer saccharum) stands. In 2016, we established a TfE within the forest to study the impact of reduced water availability on forest ecosystems. The EW site included four $20 \mathrm{~m}$ x $20 \mathrm{~m}$ plots located within two nearly monospecific stands (Figure 1), one which was dominated by black oak and the other dominated by sugar maple.

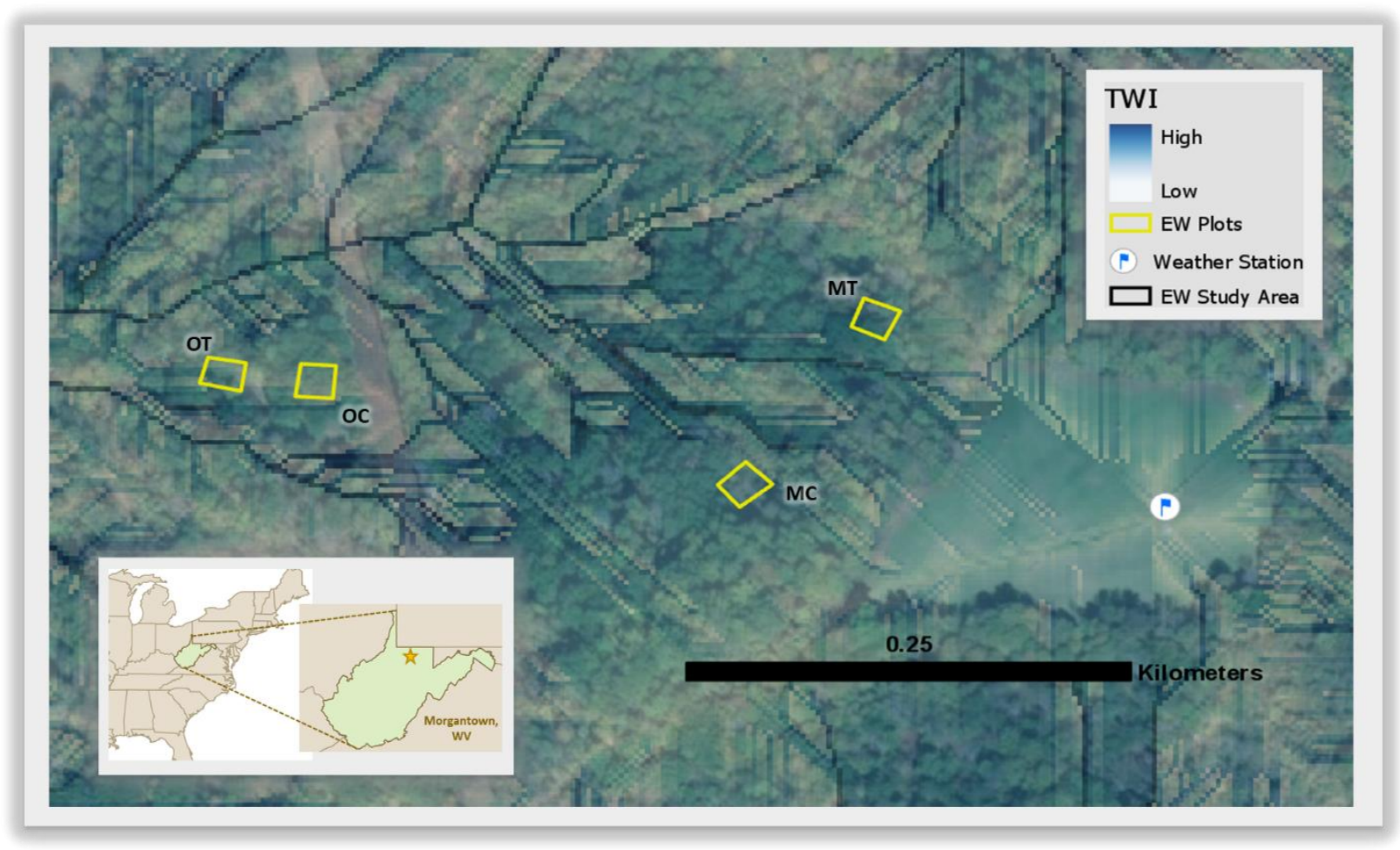

Figure 1: The location of the West Virginia Land Trust's Elizabeth Woods Nature Preserve, as well as the study plot and weather station location. The study area map includes an overlay of a site-based Topographic Wetness Index (APPENDIX 4), which is used to explain the spatial variation of soil moisture based on slope and upstream contributing area. The darker areas represent higher potential for groundwater saturation.

One plot of each species of tree was subject to a TfE treatment to simulate drought conditions using 3m tall wood and plastic gutters (Figure 2). In 2018, we applied a 50\% TfE for 
most of the growing season beginning March 11, except for June 1- July 18, where we excluded $90 \%$ of the throughfall (we did not exclude stemflow). We excluded $90 \%$ of the throughfall as an attempt to elicit a drought response during the abnormally wet 2018 growing season.

The EW study area consists of steep topographic relief, increasing roughly $92 \mathrm{~m}$ within a half kilometer from the base of the ridge to the ridge

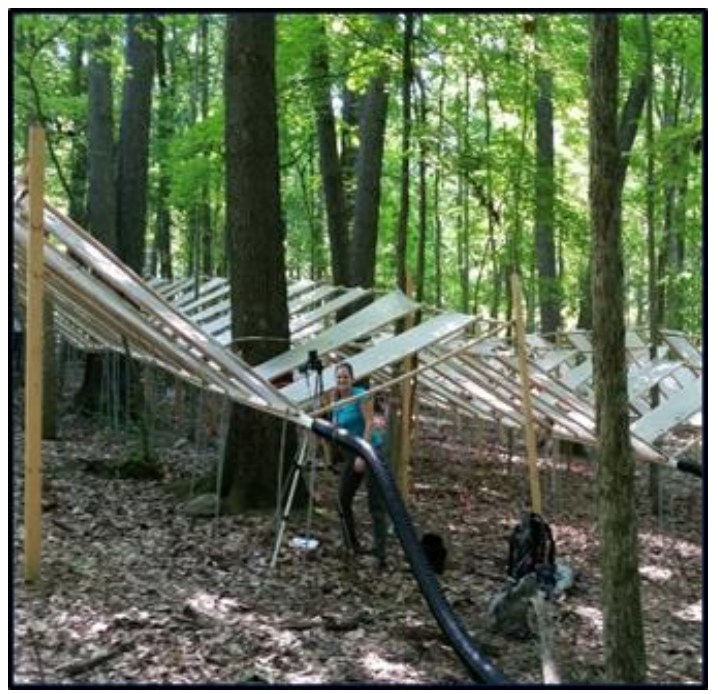

Figure 2: Throughfall exclusion gutters on the oak TfE plot at EW.

top (Figure 1). The locations of the plots are on the

west and northwest-facing slopes. The study area is less than $2 \mathrm{~km}$ from the Monongahela River, which cut into surface geology that includes sandstone, shale, limestone, clay, and coal, with some alluvial deposits of sand, gravel, silt, and clay. The average annual precipitation is 1095 $\mathrm{mm}$, and the average annual temperature is $11^{\circ} \mathrm{C}$.

\section{METHODS}

\section{Leaf level chemistry}

During the driest period of the growing season, on July $18^{\text {th }}, 2018$, I collected foliar samples from 6 trees per plot using a shotgun and steel shot to harvest small branches in the highest part of the canopy. I transported the collected sun leaves back to the laboratory with the stems wrapped in moist paper towels and stored in Ziplock bags to prevent the samples from drying out. Once in the lab, I oven-dried the leaf samples in paper bags at $60^{\circ} \mathrm{C}$ for a minimum of 48 hours. I ground the samples using a Willey Mill to pass through a $1 \mathrm{~mm}$ mesh screen before 
being analyzed for $\mathrm{C}$ and $\mathrm{N}$ concentrations and stable isotopes by the Central Appalachian Stable Isotope Facility.

$\underline{\text { Leaf angle }}$

I measured leaf angles in each plot by mounting battery-operated Wingscapes TimelapseCam Cameras on trees just outside and slightly uphill of each of the four experimental plots (oak TfE treatment, maple TfE treatment, oak and maple control). I oriented the cameras to have a direct, level view of the sun leaves within the crowns of the dominant trees in each experimental plot (McNeil et al. 2016). In mid-May 2018, I worked with a local arborist to install two cameras at different locations within each experimental plot, for a total of 8 cameras in the entire study area. These cameras recorded images on an hourly time-step from $10 \mathrm{AM}$ to 5 PM until we removed them at the end of September 2018. After retrieving the images stored on each camera's SD card, I selected images taken at solar noon on days spaced roughly two weeks apart. On each selected image, undergraduate assistants and I identified 60 leaves that were located in the middle of the image, and that were oriented in the plane of the image (Figure 3). On these selected leaves, we used a digital protractor to measure the angle from the zenith to the leaf normal (Figure 3 inset), and then used these 60 measurements per species per plot to compute the mean leaf angle for each plot. 


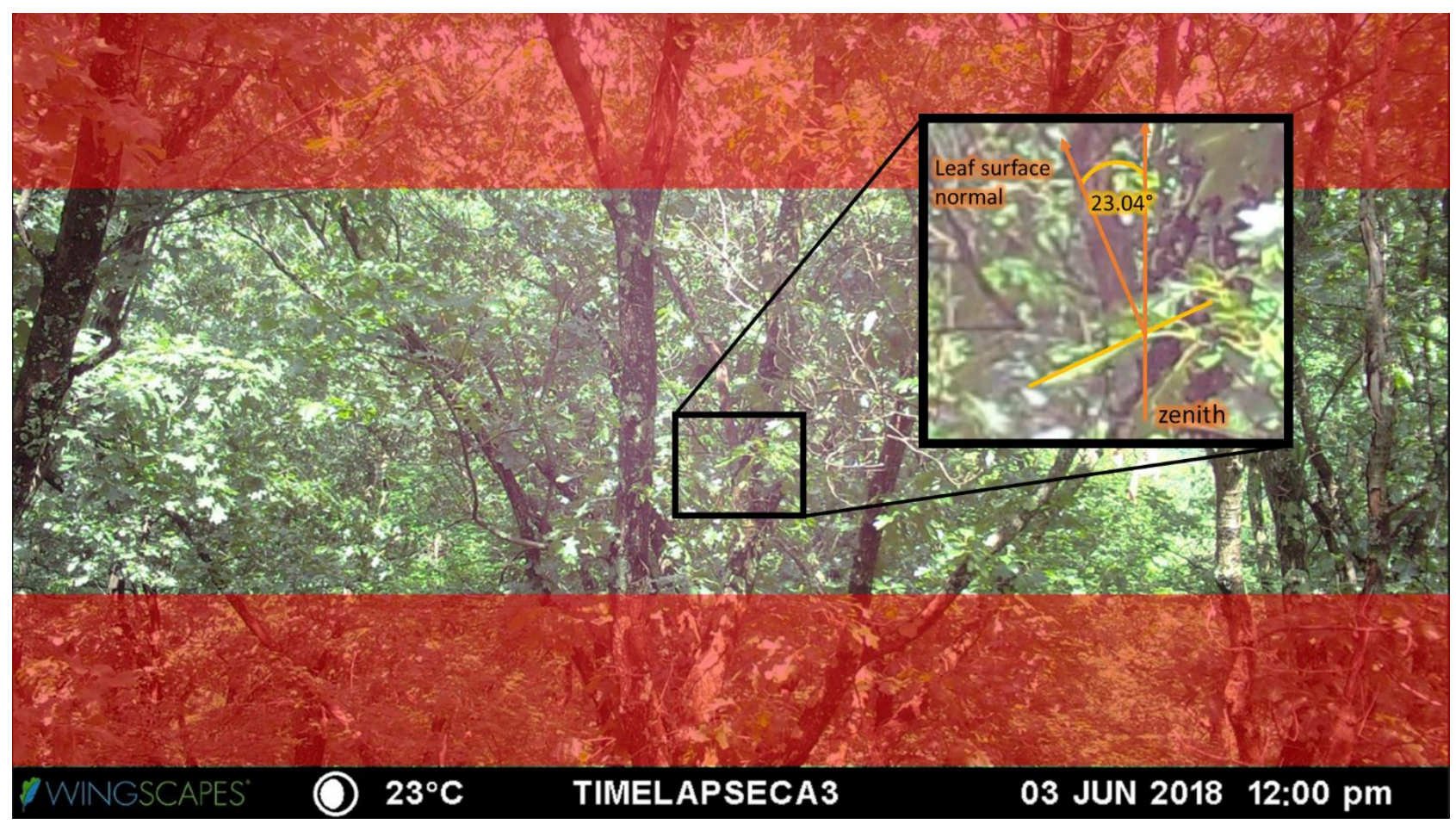

Figure 3: An example of the imagery captured from the time-lapse camera within the OT. To obtain the most accurate results, we only measured leaves that were level with the camera within the middle section of the image. The red areas represent the excluded portion. Highlighted within the black box and inset is an example of a "good" leaf candidate for digital measurement as well as a demonstration of how we obtained the measurement using the zenith and normal leaf surface.

\section{$\underline{\text { Soil moisture }}$}

I obtained my soil moisture data from Nanette Raczka, a Ph.D. candidate in the Biology Department at West Virginia University, under the advisement of Edward Brzostek. She collected moisture cores every two weeks following the Gravimetric Soil Moisture protocol. She collected six soil cores per plot at depths of $0-15 \mathrm{~cm}$, and sieved them to remove rocks, twigs, and plant materials. Then she placed roughly $40 \mathrm{~g}$ of soil into aluminum sample cups to obtain the wet and dry weights used to determine soil moisture. 
Weather Data and Water Balance Modeling

I collected precipitation, solar radiation, and other weather data (see Appendix 1) throughout the growing season from a weather station that I constructed in an open field adjacent to my study plots and on a local high point free from the influence of topographic shading (Figure 1). Following procedures detailed by Dyer (2009), I used these weather data to drive a water balance model useful for quantifying periods of diminished water availability, as well as the degree to which topography and local weather conditions may have mediated solar radiation delivery and water demand at each of the study plots (Appendix 2).

\section{$\underline{\text { Statistical Analysis }}$}

To assess the statistical significance of the differences in mean leaf angle throughout the growing season, I tested for effects of soil moisture, treatment, and species, as well as interactions among those effects using multiple regression analysis. I also completed a TwoWay Analysis of Variance (ANOVA) test ANOVA tests with post-hoc Tukey HDS on the results of my foliar isotopic analysis across species and treatment. I compared the concentration of leaf carbon found in the MT plot to the MC plot, as well as the OT plot to the OC plot for the samples collected on July $18^{\text {th }}$.

\section{RESULTS}

The lowest semi-weekly precipitation period, with $\sim 0 \mathrm{~mm}$ precipitation in the TfE plots and $17 \mathrm{~mm}$ in the control plots, was between July $1^{\text {st }}$ and July $15^{\text {th }}$ (Figure 4a). During and immediately following this period, the plots experienced the largest modeled water differences (Figure 4a), and the lowest measured shallow soil moisture (Figure 4c). Soil moisture declined 
dramatically during this period, as seen by the steep decline between July 13 and July 18 in all four study plots. During this period, the MT experienced the lowest soil moisture percentage, followed closely by the OT, OC, and lastly, the MC (Figure 4C). On July $18^{\text {th }}$, the MT had $4 \%$ less soil moisture when compared to the MC. The OT had $1 \%$ less soil moisture content compared to its control counterpart.

The foliar $\delta 13 \mathrm{C}$ measured on leaves collected on July $18^{\text {th }}$, during the peak of the driest part of the season, suggests that leaves of the MT plot had reduced stomatal conductance with a value of $-29.13 \%$ compared to the MC at $-30.28 \%$. Leaves from the OT plot had a $813 \mathrm{C}$ of $29.32 \%$ and the OC had a value of $-29.33 \%$, respectively (Figure 4B). The results of the Twoway ANOVA and post-hoc Tukey HSD test find that the MT plot had significantly higher $\delta 13 \mathrm{C}$ than the MC, but the same test found no significant difference between the OT and OC.

The mean leaf angle data displays a steady and consistent trend towards more vertical angles within the oak plots as water availability diminishes (Figure 4D). Mean leaf angles within the OT varied throughout the season from $24.17-34.36^{\circ}$, with a seasonal average of $28.77^{\circ}$. The OC ranged from $18.85-30.54^{\circ}$ with a seasonal average of $24.26^{\circ}$. Within the maple plots, mean leaf angle data remained fairly static during the growing season, ranging between $14-17^{\circ}$ in both the MT and MC. The seasonal average mean leaf angle for MT was $15.53^{\circ}$, comparable to the MC plot value of $15.77^{\circ}$. A significant difference between the OT and OC, noted on the figure with “*”, was found on June 1st, June 15th, and August 18th. The MT and MC noted a significant difference on August 29th. The measured differences between the OT and MT mean leaf angle data are significant throughout the entire growing season. 


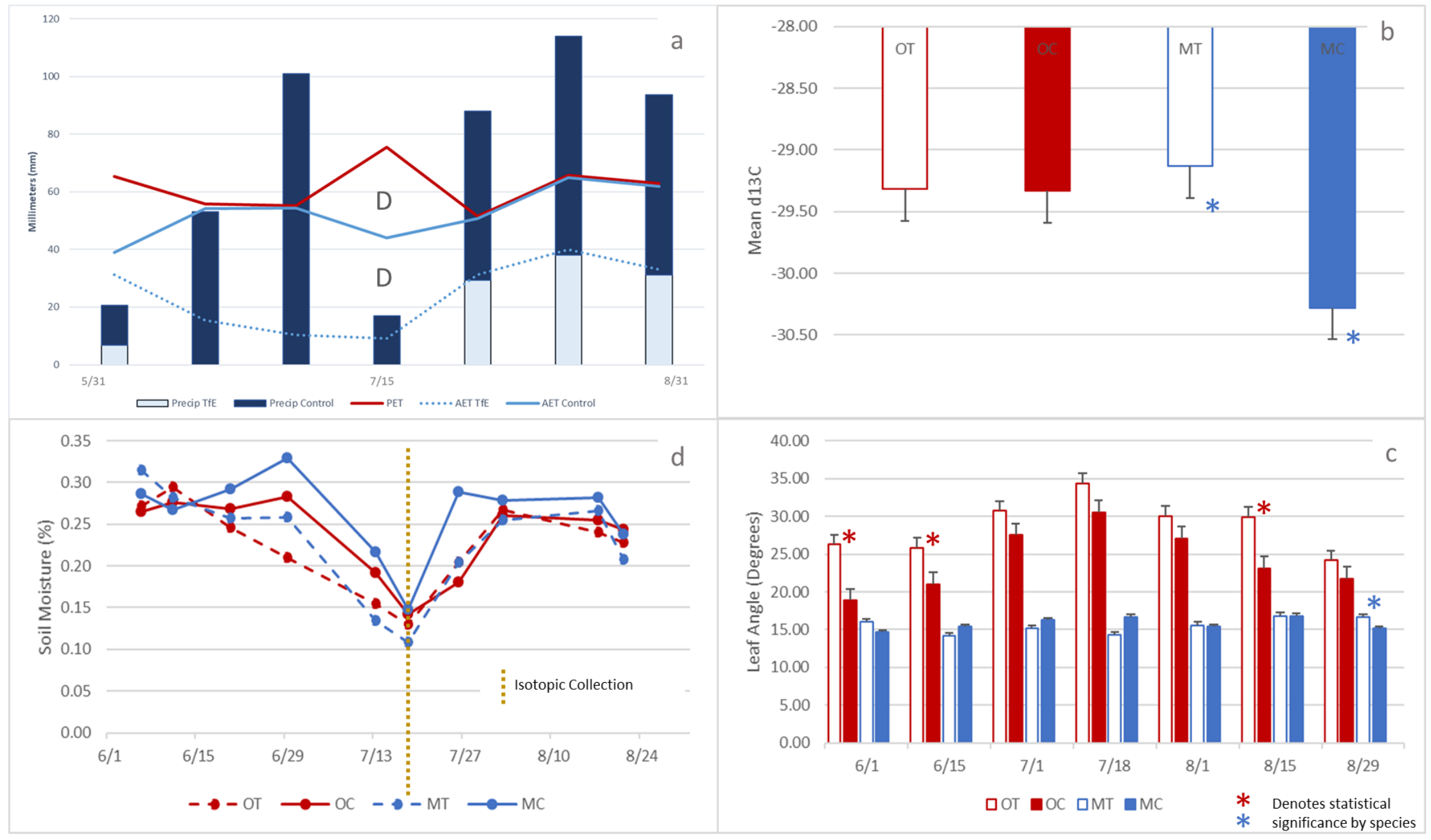

Figure 4: Results from field collection methods. (a) GIS water balance model results (APPENDIX 3) overlaid on field-measured precipitation. Plot deficits occur when AET does not meet PET and are represented with a " $D$ " (b) differences in plot measured $\delta 13 C$ collected July 18 , 2018. There was a significant difference found between MT and MC, noted with an *, (c) bi-weekly changes in leaf inclination angle by species and plot type, weeks with significant differences between TfE plots and control plots are noted with an *, and (d) bi-weekly changes in percent soil moisture by species and plot type. The dotted line represents the day the foliar isotopic analysis data was collected. 
The results of the multiple regression analysis show that the effects of soil moisture and

species on the mean leaf angle were

significant, as well as the interaction

between species and soil moisture

(Figure 5). The effects are described

using interaction terms (i.e. "control",

"ACSA"), this allows for exploration

within the specific effects. The species

impact is the strongest of the three

effects, as is reflected in the

\begin{tabular}{|c|c|c|}
\hline R2 & \multicolumn{2}{|c|}{0.89} \\
\hline $\mathbf{n}$ & \multicolumn{2}{|c|}{28} \\
\hline & p value & std beta \\
\hline \multicolumn{3}{|l|}{ Effects } \\
\hline soil moisture & 0.01 & -0.20 \\
\hline treatment (control) & 0.06 & -0.15 \\
\hline species (ACSA) & $<.0001$ & -0.85 \\
\hline \multicolumn{3}{|l|}{ Interactions } \\
\hline treatment (control)*species (ACSA) & 0.03 & 0.17 \\
\hline treatment (control)*soil moisture & 0.72 & -0.03 \\
\hline species (ACSA)*soil mositure & 0.01 & 0.21 \\
\hline treatment (control)*species (ACSA)*soil moisture & 0.89 & -0.01 \\
\hline
\end{tabular}

Figure 5: The results of the multiple regression analysis of the three effects (soil moisture, treatment, and species), on leaf angle, as well as the interactions between them. The species and soil moisture effects on leaf angle were significant $(<0.05)$ as well as the interaction between treatment and species and species and leaf angle.

standardized beta coefficient, followed by soil moisture. The interaction term ACSA, combined with the std beta of -0.85 suggest that there is a strong, negative relationship between leaf angle and maple trees, and a strong, positive relationship between leaf angle and the oak trees. The treatment effect, though not significant below 0.05 , suggests that there could be underlying interactions between the treatment and species impacting leaf angle (Figure 6). Q. velutina plot leaf angles are negatively correlated with soil moisture, as soil moisture decreases, vertical leaf angle increase, and there is a notable difference when comparing the line of best fit between the treatment

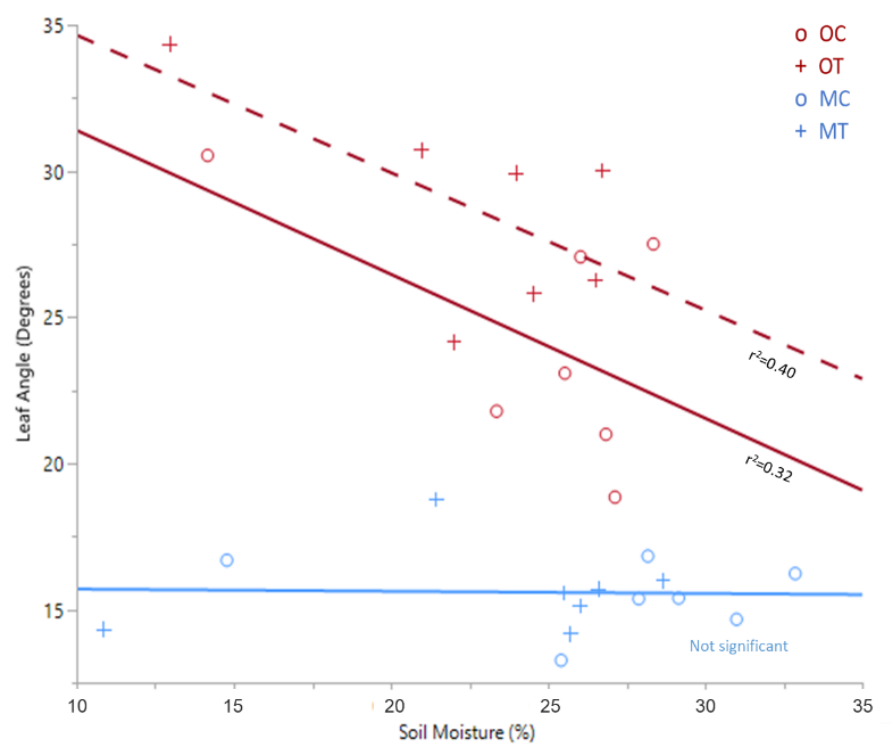

Figure 6: The relationship between soil moisture and leaf angle by species and treatment 
and control, suggesting a treatment influence on leaf angle response in $Q$. velutina. A.

saccharum treatment and control plots do not suggest any correlation between leaf angle and soil moisture. This analysis supports the results seen in Figure 4; on July $18^{\text {th }}$, measured soil moisture was at its lowest (Figure 4d), which corresponds with the more vertically measured leaves in the $Q$. velutina (Figure 4c), whereas A. saccharum leaf angles remained horizontal. The three effects combined account for $87 \%$ of the variability in the measured leaf angle.

\section{DISCUSSION}

Water availability within the plots

I designed my study to assess how different tree species use specific water management strategies in response to diminished water availability. Several lines of evidence indicate that the plots did experience comparable water shortages, particularly during the driest part of the summer, and especially in the TfE treatment plots. The hydrological environment of the study plots suggests that they are largely comparable in evaporative water demand, based on the results of a dynamic GIS-based water balance model. The water balance model included plot-specific estimates of the effect of topography on solar radiation (Appendix 2), as well as the site-level impact of clouds on solar radiation calculated using climatic data that I collected at the study site (Appendix 1 and 3). Due to small differences in slope aspect and topographic shading, the OT and MT plots were subject to slightly higher solar radiation values, which drove higher potential evapotranspiration, and slightly (e.g. by $2 \%$ ) augmented the effect of the TfE treatment on overall water differences (Appendix 3).

Topography also may have influenced plot differences in the supply of water from soil throughflow and shallow groundwater. As determined by a GIS-based topographic wetness index 
(TWI) (Appendix 4), I found that the maple plots have more potential for water flowing into the plot from uphill sources. The relationship between higher TWI and the location of maple stands supports the idea that the maple species are adapted to survive and out-compete other species within more mesic environments.

While important to consider, the impact of topography on plot differences in water availability appears to be small relative to the differences driven by rainfall and the TfE treatment effects. By incorporating the TfE reductions in throughfall into the GIS water balance model, we observed that the TfE reductions drove large reductions in actual evapotranspiration in the treatment plots, compared to their control plots (Figure 4c). The water balance model also shows that modeled decreases in water availability align well with the field-collected soil moisture data. These water balance and soil moisture data suggest that the TfE experiment was successful in intensifying low water availability conditions during July, and likely until a very large rain event completely replenished soil water to all plots on July 31 st.

Soil moisture data reflect that at the peak of the $100 \%$ TfE experiment, July 18th, there was a much larger difference between the soil moisture content in the MT and MC when compared to the OT and OC, despite experiencing similar hydrological environments and reduced through-fall. The MT plot had 4\% less soil moisture compared to the MC, whereas the OT only experienced a $-1 \%$ difference when compared to the OC. The larger difference in soil moisture between the MT and MC, compared to the OT and OC, suggests that under treatment conditions, the MT is using more water despite having the largest TWI. This result aligns well with species-specific transpiration data collected using the heat pulse method during the 2018 growing season (Guillén et al., ND). The higher measured soil moisture content in the OT 
compared to OC after heavy rainfall events suggest that the water supply in the OT plot has larger topographic influences, as is reflected by the TWI.

Leaf angle vs. Stomatal responses to reduced water availability

While A. saccharum had fairly horizontal and static mean leaf angles through the season, leaf angles of the $Q$. velutina trees were more vertical and dynamic in response to the TfE treatment and changes in soil moisture during the growing season (Figure $\mathbf{4 b}$ ). At the beginning of the season, $Q$. velutina trees in the TfE plot (i.e., OT) had a significantly more vertical mean leaf angle than the control plot. But, as soil water declined in July, the $Q$. velutina trees increased in mean leaf angle, with the control plot catching up to the treatment plot. In both plots, there is a direct correlation between reduced soil moisture and increased leaf angle. This relationship is strongly driven by the measurements taken at the peak of the drought. Increased sampling dates could lend more explanation to the response of each species, as well as the shape of the relationship to changes in soil moisture. The similarities in response between the treatment and control in this period of reduced water availability, further support the responsive and dynamic nature of the $Q$. velutina leaves under limited water availability. This finding aligns with the review of the vertical orientation of leaves as a stress avoidance technique (Zanten et al., 2010), where leaf orientation alters the interception of radiation, which helps maintain more favorable energy and water balance. The more vertical leaf angles reduce the solar radiation load leaves are subject, which prevents leaf temperature increases that would ultimately lead to increased transpiration rates or, in the case of isohydric plants, a necessary reduction of stomatal conductance. 
When faced with reduced water availability, we observed that $A$. saccharum trees do not change their leaf angle, but rather reduce stomatal conductance to preserve water (Figure 4b). The results of the $\delta 13 \mathrm{C}$ analysis within the oak species show that the species did not significantly change between the control and treatment plots, suggesting that they are less isohydric. This result aligns with other studies (Zweifel et al., 2009), where the Quercus species were also found to keep stomata more open during drought conditions.

The patterns displayed in precipitation, reflected in the soil moisture content, inversely, match that of the leaf angle in the oak trees, which do not show signs of the stomatal control present within the maple trees. These results support my hypothesis regarding different water management strategies between oak and maple trees and suggest that the oak trees could be better adapted to surviving in reduced water environments. My findings lend support to the theory of hydrisity with evidence that anisohydric species use a mechanism of increased leaf angle in response to low water availability. In contrast, the isohydric water management strategy was to limit water loss by reducing stomatal conductance.

This study would benefit from the inclusion of more data. Replicating the design with more cameras placed throughout the canopy would help obtain more representative leaf angles across the crown as a whole and to reduce the impact of technical errors and malfunctions (i.e., camera malfunctions, branches breaking and dislodging cameras, stem growth obstructing the lens). It would also be beneficial to include cameras at different heights to test whether the $Q$. velutina are altering leaf angles uniformly throughout the crown, or if there are varying degrees based on the vertical location within the crown (i.e., leaves lower in the crown, more shaded, are measuring more horizontal angles than those in the upper, sunny reaches; Ford and Newbould, 1971). 
We focused one crucial crown architectural trait response to water availability, leaf angle. Studies have shown that crown productivity is directly linked to their ability to maximize the amount of light interception, which is also influenced by the vertical distribution and density of leaves (Niinemets, 2009; Ellsworth and Reich, 1993; Fotis and Curties, 2016). It is expected that as the Q. velutina trees angle their leaves more vertically, the crown will open, allowing more light to be received in the lower crown. Future work on the combined impact of these three traits, and their holistic response to changes in water availability, could increase our understanding of the impact of reduced water availability forest functioning as a whole. It would also be beneficial to measure the response mechanisms in more species, in varying environments, to further out species-specific response along the hydrisity spectrum and aid in predictions of whole-scale forest response to climate change and inform better management practices. Lastly, it is known that as climate shifts there will be an impact on forest structure and species composition globally (Kirschbaum et al. 1996; Lines et al, 2010), and that forest composition will then impact regional and global climate by altering energy and water fluxes as well as impacting albedo (Bonan et al., 2003; Tajchman et al., 2007; Guo et al., 2017). Vegetation dynamics are known to impact forest functioning and productivity ( Donohue et al., 2007), and based on the results of this study, the inclusion of the response mechanisms of different species to changes in water availability could benefit forest productivity models as well as climate models. This inclusion could aid in assessing the sustainability of the world's forest eco-services.

\section{CONCLUSION}

Overall, my results lend strong support to my two original hypotheses on the relationship between species crown structure adaptations and their response to drought. Reduced 
water availability led to increasingly vertical leaf angles in the Quercus velutina species, especially within the TfE plot, and at the peak of the drought, to combat water loss without evidence of stomatal closure. The more mesic-adapted Acer saccharum trees maintained a consistent horizontal leaf angle throughout the growing season in both the TfE plot as well as the control, and evidence of stomatal closure was apparent in the TfE plot, especially at the peak of the drought. The adaptive capabilities of these species were apparent in measured soil moisture data, which shows a greater loss in percent moisture within in MT plot compared to the OT.

The ability to predict species response to changes in water availability in the face of global climate change is a crucial first step in beginning to understand and predict overall forest response to climate change. The specific focus on crown architecture not only addresses a key uncertainty in species responses to water availability but can also provide a much-needed means to scale up tree species responses to water availability using the spectral reflectance properties measurable from satellite instruments. This information could establish a further understanding of Earth's processes, and the impacts of climate variation aid in improving existing climate models as well as better informed decision making and planning. 


\section{REFERENCES}

American Society of Civil Engineers (1990) Evapotranspiration and irrigation water requirements. American Society of Civil Engineers, New York

Beven, K. J. and Kirkby, M. J.: A physically based, variable contributing area model of basin hydrology. Hydrological Sciences Bulletin, 24, 43-69, 1979.

Budyko, M. I.: Climate and Life, Academic, New York, 508 pp., 1974.

De Castro F, Fetcher N. 1999. The effect of leaf clustering in the interception of light in vegetal canopies: theoretical considerations. Ecological Modelling 116: 125-134.

Chaves M.M., 1991. Effects of water deficits on carbon assimilation. Journal of Experimental Botany 42:1-16.

Chaves, M.M.; Pereira, J. S.; Maroco, J.; Rodrigues, M. L. ; Ricarddo, C. P. P. ; Osorio, M. L.; Carvalho, I.; Faria, T.; Pinhero, C. (2002) How Plants Cope with Water Stress in the Field? Photosynthesis and Growth, Annals of Botany, Volume 89, Issue 7, June 15, 2002, Pages 907-916, https://doi.org/10.1093/aob/mcf105

Cernusak LA, Arthur DJ, Pate JS, Farquhar GD. 2003. Water relations link carbon and oxygen isotope discrimination to phloem sap sugar concentration in Eucalyptus globulus. Plant Physiology 131: 1544- 1554.

Donohue, R.J., Roderick, M.L., McVicar, T.R. On the importance of including vegetation dynamics in Budyko's hydrological model. Hydrology and Earth System Sciences, 11 (2007), pp. 983-995Dyer, James M., 2009. Assessing Topographic Patterns in Moisture use and Stress using a Water Balance Approach. Landscape Ecology 24.3, 391-403.

Dyer, James M., 2017. Water Balance Toolbox for ArcGIS [v.3.1] Beta Release. 
Dyer, James M., 2009. Assessing Topographic Patterns in Moisture use and Stress using a Water Balance Approach. Landscape Ecology 24.3, 391-403.

Ellsworth, D.S., Reich, P.B. 1993. Canopy structure and vertical patterns of photosynthesis and related leaf traits in deciduous forest. Oecologia 96, 169-178.

Ehleringer JR, Werk KS. 1986. Modifications of solar radiation absorption patterns and implications for carbon gain at the leaf level. In: Givnish T, eds. On the Economy of Plant Form and Function, 57-82.

Falster DS Westoby M Leaf size and angle vary widely across species: what consequences for light interception? New Phytologist 2003158509525

Fahey, R.T., Fotis, A.T., Woods, K.D., 2015. Quantifying canopy complexity and effects on productivity and resilience in late-successional hemlock-hardwood forests. Ecol. Appl. 25, 834-847. doi:10.1890/14-1012.1

Farquhar GD, O'Leary MH, Berry JA (1982) On the relationship between carbon isotope discrimination and the intercellular carbon dioxide concentration in leaves. Aust J Plant Physiol 9:121-137

Farquhar GD, Ehleringer JR, Hubick KT (1989) Carbon isotope discrimination and photosynthesis. Annu Rev Plant Physiol Plant Mol Biol 40:503-537 Ford, E. D., and Newbould, P. J. 1971. The leaf canopy of a coppiced deciduous woodland. I. Development and structure. J. Ecol. 59: 843-862.

Fotis, A.T., Curtis, S., 2017. Effects of structural complexity on within-canopy light environments and leaf traits in a northern mixed deciduous forest. Tree Physiol. 1-10. 
Gates D.M., W. Tantraporn. The reflectivity of deciduous trees and herbaceous plants in the infrared to 25 microns. Science, 115 (1952), pp. 613-616

Gates D.M., H.J. Keegan, J.C. Schleter, V.R. Weidner. Spectral properties of plants. Appl. Optics, 4 (1965), pp. 11-20

Givnish T.J. (1984) Leaf and Canopy Adaptations in Tropical Forests. In: Medina E., Mooney H.A., Vázquez-Yánes C. (eds) Physiological ecology of plants of the wet tropics. Tasks for vegetation Science, vol 12. Springer, Dordrecht

Granier, C. and Tardieu, F. (1999) Water Deficit and Spatial Pattern of Leaf Development. Variability in Responses Can Be Simulated Using a Simple Model of Leaf Development. Plant Physiology Feb 1999, 119 (2) 609-620; DOI: 10.1104/pp.119.2.609

GridMET dataset, University of Idaho Climatology Lab

Guillén, LA, Brzostek, E, McNeil, B., Raczka, N., Casey, B., Turner, B., and Zegre, N. Differences in sap velocities of Acer saccharum (L.) and Quercus velutina (Lam.) in West Virigina: environmental controls and implications for future forest evapotranspiration. In progress.

Guo D, Westra S, Maier HR (2017) Sensitivity of potential evapotranspiration to changes in climate variables for different Australian climatic zones. Hydrol Earth Syst Sci 21:21072126. https://doi.org/10.5194/hess-21-2107-2017

Itakura, K.; Hosoi, F. Estimation of Leaf Inclination Angle in Three-Dimensional Plant Images Obtained from Lidar. Remote Sens. 2019, 11, 344.

Kirschbaum, M.U.F., P. Bullock, J.R. Evans, K. Goulding, P.G. Jarvis, I.R. Noble, M. Rounsevell and T.D. Sharkey. 1996. Ecophysiological, ecological, and soil processes in terrestrial 
ecosystems: a primer on general concepts and relationships. In Climate Change 1995. Impacts, Adaptation and Mitigation of Climate Change: Scientific-Technical Analyses. Contribution of WG II to the Second Assessment Report of the IPCC. Eds. R.T. Watson, M.C. Zinyowera and R.H. Moss. Cambridge University Press, Cambridge, pp 57-74.

Knipling E.B. Leaf reflectance and image formation on color infrared film. P.L. Johnson (Ed.), Remote Sensing in Ecology, Univ. of Georgia Press, Winter Haven, Florida (1969), pp. 1729.

Kozlowski, T. T. and Pallardy, S. G.: Acclimation and adaptive responses of woody plants to environmental stresses, Botan. Rev.68, 270-334, 2002.

Lambers H, Chapin FS, Pons TL. 1998. Plant physiological ecology. New York, USA: Springer. Lines ER, Coomes DA, Purves DW (2010) Influences of forest structure, climate, and species composition on tree mortality across the eastern US. PLoS ONE 5(10): e13212, 10.1371/journal.pone.0013212.

Mann, M.E., Rahmstorf, S., Kornhuber, K, Steinman, B.A., Miller, S.K., Coumou, D., 2017. Influence of Anthropogenic Climate Change on Planetary Wave Resonance and Extreme Weather Events. Scientific Reports, 7:46822. DOI: 10.1038/srep46822

McNeil, B.E., Pisek, J., Lepisk, H., Flamenco, E.A., 2016. Measuring leaf angle distribution in broadleaf canopies using UAVs. Agric. For. Meteorol. 218-219, 204-208. doi: 10.1016/j.agrformet.2015.12.058

Nagasuga, K., Uchida, S., Kaji, H., Hayakawa, Y., Kadowaki, M., Fukunaga, A., Nose, S., Umezaki, T. 2013a. Water condition controls inclination angles of leaflets and petioles of soybean (Glycine max L.). Environ. Control Biol. 51: 79-84. 
National Oceanic and Atmospheric Administration. (2017). MORGANTOWN LOCK AND DAM, WV US Daily Summaries Station Detail. https://www.ncdc.noaa.gov. Accessed $[10 / 21 / 2017]$

National Climatic Data Center (2012) State of the Climate. NCDC Climate Monitoring. URL Niinemets, Ü. A review of light interception in plant stands from leaf to canopy in different plant functional types and in species with varying shade tolerance. Ecol. Res. 25, 693714 (2010) Oki, T. and Kanae, S., 2006. Global Hydrological Cycles and World Water Resources. Science, 1068-1072.

Paybins, K.S., 2003. Flow Origin, Drainage Area, and Hydrologic Characteristics of Headwater Streams in the Mountaintop Coal-mining Region of Southern West Virginia, 2001-01. Water Resources Investigations Report 02-4300. US Geological Survey, Charleston, WV.

Pisek, J., Y. Ryu, and K. Alikas (2011), Estimating leaf inclination and G-Function from leveled digital camera photography in Broadleaf Canopies, Trees, 25(5), 919-924, doi:10.1007/s00468-011-0566-6.

Rahmstorf, S., Kornhuber, K, Steinman, B.A., Miller, S.K., Coumou, D., 2017. Influence of Anthropogenic Climate Change on Planetary Wave Resonance and Extreme Weather Events. Scientific Reports, 7:46822. DOI: 10.1038/srep46822

Roderick M.L., Farquhar, G.D. 2011. A simple framework for relating variations in runoff to variations in climatic conditions and catchment properties. Water Resources Research 47: W00G07.State of Ohio Environmental Protection Agency (2009), Total Maximum Daily Loads for the White Oak Creek Watershed. Final Report., A2-A23. 
Rodrigues M.L., Pacheco C.A., Chaves M.M. (1995) Soil-plant relations, root distribution and biomass partitioning in Lupinus albus L. under drought conditions. Journal of Experimental Botany 46:947-956.

Ryan, Michael G., 2011. Tree responses to drought. Tree Physiology, Volume 31, Issue 3, pages 237-239, https://doi.org/10.1093/treephys/tpr022

Sade N., Gebremedhin A., Moshelion M. (2012). Risk-taking plants: anisohydric behavior as a stress-resistance trait. Plant Signal. Behav. 7, 767-770. 10.4161/psb.20505

Sharp R.E. and Davies W.J. (1989) Regulation of growth and development of plants growing with a restricted supply of water. Plants under stress. Cambridge: Cambridge University Press, 71-93.

Soil Survey Staff, Natural Resources Conservation Service, United States Department of Agriculture. Web Soil Survey. Available online at https://websoilsurvey.nrcs.usda.gov/. Accessed [10/21/2017].

Sorensen, R., Zinko, U., Seibert, J. (2006) On the calculation of the topographic wetness index: evaluation of different methods based on field observations. Hydrology and Earth System Sciences Discussions, European Geosciences Union, 10 (1), pp.101-112.

St. Clair, S., Sharpe, W.E., Lynch, J.P. (2008) Key interactions between nutrient limitation and climatic factors in temperate forests: a synthesis of the sugar maple literature. Canadian Journal of Forest Research. 38:401-414, https://doi.org/10.1139/X07

S.J. Tajchman, H. Fu, J.N. Kochenderfer, C. Pan. Spatial characteristics of topography, energy exchange, and forest cover in a central Appalachian watershed. (2007). Proceedings, 
10th Central Hardwood Forest Conference, For. Sev. Northeast For. Exp. Sta. Gen. Tech. Report NE-197, USDA

Tardieu, F., and Simonneau, T.(1997) Variability among species of stomatal control under fluctuating soil water status and evaporative demand: modelling isohydric and anisohydric behaviours, Journal of Experimental Botany, Volume 49, Issue Special_Issue, March 1 1998, Pages 419-432, https://doi.org/10.1093/jxb/49.Special_Issue.419

Thornthwaite, C.W. and Mather, J.R. (1957) Instructions and tables for computing potential evapotranspiration and the water balance Publ. Climatol., 10 (3)

Turner, I.M. (1994) Sclerophylly: primarily protective? Functional Ecology 8: 669-675.

U.S. Geologic Survey. (2010) A Modified Thornthwaite - Mather Soil-Water-Balance Code for Estimating Groundwater Recharge. Chapter 31os Section A, Groundwater, of Book 6, Modeling Techniques.

Walther, G.R., Post, E., Convey, P., Menzel, A., Parmesan, C., Beebee, T., Fromentin, J.M., Hoegh-Guldberg, O., Bairlein, F., et al., 2002. Ecological responses to recent climate change. Nature, 416.

van Zanten, M., Pons, T.L., Janssen, J.A.M., Voesenek, L.A.C.J. and Peeters, A.J.M. (2010) On the Relevance and Control of Leaf Angle. Critical Rev. Plant Sci. 29, 300- 316.

Zweifel, R., Rigling, A., Dobbertin, M. (2004) Species-specific stomatal response of trees to drought- a link to vegetation dynamics? Journal of Vegetation Science. 20, 442-454. 


\title{
Education
}

\author{
Brittany N. Casey \\ Graduate Teaching Assistant \\ Department of Geology and Geography \\ West Virginia University \\ Morgantown, WV 26505 \\ Bnc0015@wvu.edu
}

M.A. Geography

West Virginia University, Morgantown, WV

in progress

Advisor Dr. Brenden McNeil

Graduate Certificate in GIS and Spatial Analysis

2019

Agriculture, Natural Resources \& Design

West Virginia University, Morgantown, WV

Advisor Dr. Michael Strager

GPA: 4.0

B.S. Geographic Science

2011

James Madison University, Harrisonburg, VA

Concentration: Environmental Conservation, Sustainability, and Development and Applied

Geographic Information Systems

Graduated Cum Laude

Research, Presentations, Internships, and Publications

Graduate Thesis (In progress) - Leaf angle and leaf stomata responses to experimental drought in Quercus velutina and Acer saccharum

GIS water balance models for evaluating uncertainty in a forest drought experiment- Institute of Water Security and Science 2018 Spring Conference: poster presentation

GIS Research and Publication- Topographic and hydrographic GIS datasets for the Afghan

Geological Survey and U.S. Geological Survey 2013 mineral areas of interest Report

Senior Capstone Research Project- The Implications of Globalization and an Altering Natural

Environment on Indigenous Populations: A Case Study of the Indigenous BriBri of Costa Rica

JMU on the Farm- Internship research conducted on local farms in Harrisonburg, VA to learn and aid in the implementation of small-scale farming techniques, localization, renewable energy, sustainable agriculture techniques and installment of best management practices

Study Abroad- London, England: Urban Geography Study, Costa Rica: Sustainable Living

Academic

NASA WVSGC Fellowship Scholar

Geography Graduate Group, Member at Large

Starting President of Gamma Theta Upsilon, International Geographic Honor Society

CISAT Endowment Scholarship, Roop Scholarship, Dawson Math/Science Scholarship

FFA American Degree Recipient 
Virginia Master Naturalist Program 2013

Work Experience

Ecologist: Resource Environmental Solutions, LLC

May 2019- Present

- Performs all aspects of field work, collecting and organizing data, writing technical reports, and preparing permit applications

- Knowledgeable of state and federal environmental regulations and permitting processes

- Proficient in stream and wetland restoration design, construction, and monitoring techniques

- Leads team of field ecologist to perform various tasks including wetland delineation, stream assessments, biotic sampling

Graduate Teaching Assistant: West Virginia University, Geography Dept.

August 2017-May 2019

- Taught undergraduate courses relating to physical geography and GIS

- Wrote, administered, and graded lab exercises and test

- Coordinated relevant field experiences

Research Assistant: West Virginia University, Biology Dept.

May-August 2017

- Collected field data-soil core samples, tree root exudates, canopy leaf samples

- Conduct root enzyme analysis

- Measured in field leaf water potential using a pressure chamber

- Measured photosynthesis in the field using a LI-COR portable photosynthesis system

- Assisted in the collection of canopy level trait data using UAVs

Program Manager/Educator: The Chesapeake Bay Foundation

March 2014-July 2017

- Manager of the Virginia Watershed Education Program

- Develop and implement one-day field experiences for 6th-12th grade students based upon curriculum needs and state standards

- Execute programs, such as boating skills, educational activities, wildlife observation, biological sampling, water quality testing, ecosystem and watershed concept for all students/teachers while assessing and managing risk factors

- Adapt program content based upon grade/age level of students, weather, seasons, and group dynamics

- Maintain/repair all vehicles, boats, safety equipment, and educational gear

- Assist other educational programs, communicate progress with other departments, and develop and implement one-year program plan that is in alignment with CBF's strategic plan

- Assist with farm operations' including animal care, tractor/ equipment maintenance, planting and harvest of crops for CSA, design and implement education garden (while on Clagett Farm)

Farm Hand: Weaver Brother's Farm, Bridgewater, VA,

May 2008-March 2016

- Responsible for milking 150 cows twice a day and feeding and caring for calves

- Aided in the implementation of BMPs and sustainable practices

- Required to maintain sanitation standards

- Assist veterinarian with routine procedures

Program Coordinator: Horizons Outdoor Learning Center, Harrisonburg, VA April 2012-March 2014

- Provide day-to-day management of program logistics to assure safety, high quality program standards and appropriate staffing plans

- Lead development and maintenance of program standards, policies, and procedures for OLC and Camp Horizons Outdoor Program staff

- Developed and maintained program budget while also bringing in a positive revenue stream to further develop Outdoor Learning Center programs 
- Served as a contractor to the United States Geologic Survey (USGS)

- Used remote sensing and GIS methodology coupled with hydrologic and geomorphic modeling techniques to monitor and estimate mineral deposits in Afghanistan and Africa

- Constructed and edited DEMs to be used in modeling processes and analysis

- Conducted research using Advanced Land Observing Satellite (ALOS) Panchromatic Remotesensing Instrument for Stereo Mapping (PRISM) imagery in the Northern Virginia area to determine the relationship between autocorrelation score and DEM accuracy/uncertainty and to determine the best stereopair combination to use per land-class delineation

Skills

- Proficient in ArcEditor, R/Rstudio, Microsoft Office, JMP, Geoda, Adobe Photoshop

- Extensive use of topographic maps and images collected by satellites and aircraft

- Introductory level knowledge in python scripting in ArcGIS, JavaScript

- Experienced in cartographic design, vector and raster datasets, data formatting and converting, data entry, database management, metadata creation and preparation

- Experienced operating GPS equipment, digitizers, scanners, portable LiDAR, UAVs, portable photosynthesis

- Proficient in general laboratory skills including safety protocols, proper measuring, mixing, sterilization, handling and disposal of chemicals, and following detailed laboratory protocols and procedures as written

- Basic soil sampling techniques for nutrient analyzation and the USDA Web Soil Survey

- Proficient in water quality sample, testing, analyzing, and maintenance of equipment including colorimeters, $\mathrm{pH}$ and conductivity meters, dissolved oxygen probes, and many chemical testing techniques

- Tree classification, macroinvertebrate identification

- Knowledgeable in many best management practices and implementation techniques

- Strong verbal and written communication skills

- Experienced in field work, data collection, and research project development and implementation as well as research writing, publication, and presentation

\section{Extracurricular}

- Wilderness First Responder

- American Canoe Association (ACA) trained and certified instructor L3

- Professional climbing guide 


\section{APPENDIX 1- Weather Data}

Having site-specific weather data is important for reducing the uncertainties and increasing our understanding of specific climatic variability on our study site. In June of 2018, I installed a weather station in a large open field adjacent to my study plots (Figure 1) and on a local high point free from the influence of topographic shading. This station logged hourly averages of solar radiation in watts per meter squared $(\mathrm{W} / \mathrm{m} 2)$, the average temperature in degrees Celsius $\left({ }^{\circ} \mathrm{C}\right)$, and the sum of total precipitation in millimeters $(\mathrm{mm})$. I created

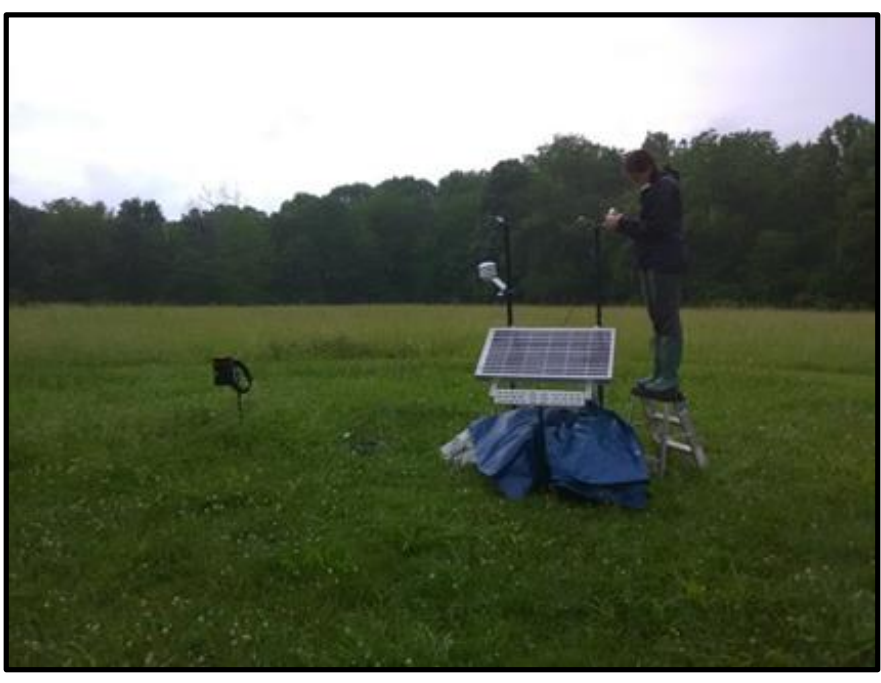

Figure 1: Installing the weather station adjacent to the EW plots where there would be no impact from the surrounding topography or forest.

a code for summarizing the hourly data

into biweekly averages or sums, depending on the variable. I used the data from this station to inform a water balance model, as well as to relate climatic trends impacting the study plots throughout the growing season to measured changes in species adaptive features.

To supplement gaps in the field-collected weather data, I created relationships between known field-measurements of precipitation and temperature and records from the Weather Underground Morgantown Municipal Airport Station. I also plotted field measured solar radiation values against daily solar energy production readings from solar panels on a home in Morgantown (McCasi Power and Light). Readings from both stations evidence the effect of clouds on solar radiation data, and both stations were located within 10 miles of the EW plots. I 
plotted the daily relationship between the overlapping data, from June 1- December 31, 2018, and used these relationships to predict the missing field measurements for April and May 


\section{APPENDIX 2- Solar radiation modeling for Water balance}

The amount of solar radiation an area is subject to is dependent on many factors, including latitude, time of year, topography, cloudiness, and land cover. Various studies have discussed these factors and their importance in driving PET (Thornethwaite, 1948; Fu and Rich, 2002; Katul and Novik, 2009; Dyer, 2009). To be able to understand species response to changes in water availability, it is necessary to assess the impact of topography and cloudiness at EW on water demand.

I used the Standard Overcast Sky Model (SOCM) with on-site derived parameters for diffuse proportion (D) and transmittivity (T) of global radiation to account for the daily weather conditions and reflect the amount of solar radiation each plot received more accurately. The SOCM considers the solar zenith angle, and adjust diffuse radiation accordingly, accounting for variations in topography. For the determination of atmospheric parameters, solar radiation was measured in the field using a Campbell Scientific CM3 Pyranometer located at the weather station I constructed next to my study plots. The summarized data provides a snapshot of the amount of solar radiation received at that timestamp. I summed the bi-weekly amounts of recorded solar radiation (in Wh/m2). Utilizing a tool designed by Dyer (2018), I ran every possible combination of $\mathrm{D}$ and $\mathrm{T}$ for each bi-weekly period. I compared the modeled solar radiation to the known value recorded by the weather station. The combination that produced a modeled output that most closely matched the field measured results was selected to represent the atmospheric parameters for that period (Table 1). 


\begin{tabular}{|c|c|c|c|c|c|c|}
\hline Date & d & t & ARC GHI & Field GH & Difference & Error (\% diff) \\
\hline April 1-15 & 0.2 & 0.5 & 119896 & 117764 & -2132 & 1.79 \\
\hline April 16-30 & 0.5 & 0.4 & 126919 & 128766 & 1847 & 1.44 \\
\hline May 1-15 & 0.4 & 0.4 & 141673 & 143110 & 1437 & 1.01 \\
\hline May 16-31 & 0.2 & 0.5 & 153078 & 156458 & 3380 & 2.18 \\
\hline June 1-15 & 0.9 & 0.1 & 126364 & 125814 & -550 & 0.44 \\
\hline June 16-30 & 0.3 & 0.4 & 132387 & 134740 & 2353 & 1.76 \\
\hline July 1-15 & 0.7 & 0.3 & 176001 & 175878 & -123 & 0.07 \\
\hline July 16-31 & 0.5 & 0.3 & 173792 & 172544 & -1248 & 0.72 \\
\hline Aug 1-15 & 0.7 & 0.3 & 148365 & 150306 & 1941 & 1.30 \\
\hline Aug 16-31 & 0.7 & 0.3 & 148365 & 150124 & 1759 & 1.18 \\
\hline Sept 1- 15 & 0.1 & 0.6 & 115632 & 115782 & 150 & 0.13 \\
\hline Sept 16-30 & 0.2 & 0.5 & 96979 & 98174 & 1195 & 1.22 \\
\hline
\end{tabular}

Table 1: Chart displaying the results of bi-weekly modeled GHI compared with field measured GHI, the amount and percent different, as well as their associated parameters of $\mathrm{D}$ and $\mathrm{T}$.

I used the best D-T combinations to create solar radiation grids for each bi-weekly period. I calculated the average amount of solar radiation across each plot, per biweekly period by using zonal statistics on each of the solar radiation grids produced. I used the averages to inform the plot-level water balance models as specific inputs for each plot.

Plot-specific solar radiation amounts varied across the species-specific, and treatment plots. On average, the OT experienced roughly $4 \%$ higher solar radiation when compared to the OC, the MT experienced an average of 5\% higher solar radiation when compared to the MC, the MT had an average of $1.2 \%$ higher solar radiation than the OT, and the MC had $0.38 \%$ higher plot average solar radiation when compared to the OC (Figure 1, Table 2). 


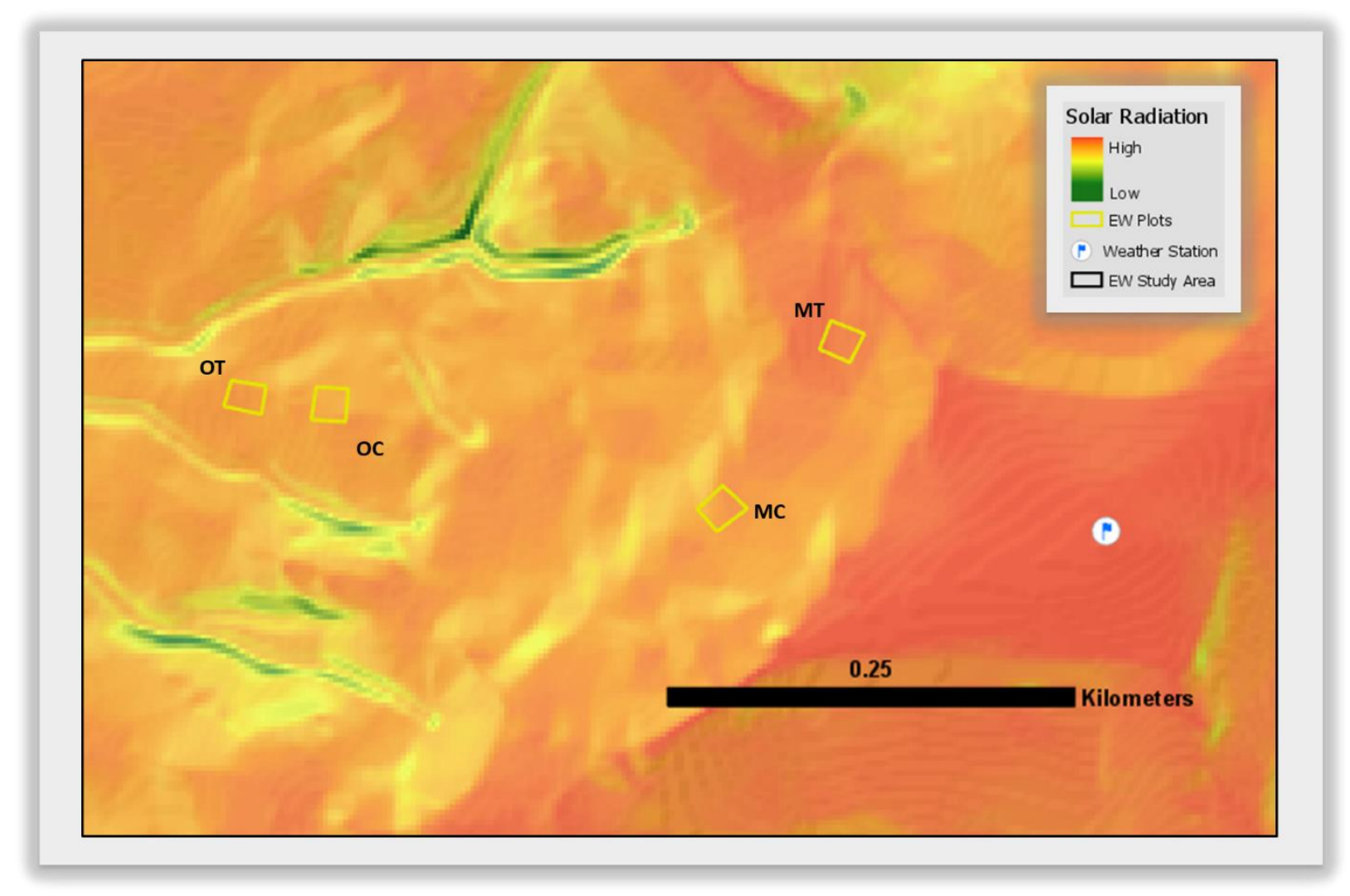

Figure 1: Solar radiation grid produced for the bi-weekly period of June 1- June 15 displaying the site level variations due to topography and atmospheric conditions.

\begin{tabular}{|r|c|c|c|c|c|c|c|c|}
\hline \multicolumn{7}{|c|}{ Solar Radiation $\mathbf{( W h} / \mathbf{m}^{\mathbf{2}}$ ) } \\
\hline & June 1-15 & June 16-30 & July 1-15 & July 16-31 & Aug 1-15 & Aug 16-31 & Sept 1-15 & Sept 16-30 \\
\hline OT & 70117.07 & 65374.87 & 92774.69 & 60598.62 & 81796.35 & 77319.94 & 60593.85 & 42313.68 \\
\hline OC & 69169.56 & 63289.83 & 90719.92 & 58552.47 & 79400.02 & 74603.66 & 54885.55 & 37765.33 \\
\hline MT & 71547.09 & 65766.38 & 93729.34 & 61236.06 & 82765.41 & 78346.24 & 61261.90 & 42996.61 \\
\hline MC & 70126.28 & 63284.92 & 91151.90 & 58744.09 & 79799.75 & 75004.81 & 54636.62 & 37670.71 \\
\hline
\end{tabular}

Table 2: Table of the mean, bi-weekly analysis of plot level solar radiation as impacted by topography and daily atmospheric conditions. On average, MT was subject to the highest amount of solar radiation followed by the OT, the MC, and lastly, the OC. The highlighted section of June 1-15 is reflected in the map above. 


\section{APPENDIX 3- Water Balance Models}

I used a GIS-based water balance modeling approach to assess fine-scale moisture demand and availability (Dyer 2009) within the EW study plots during the 2018 growing season. This model dynamically integrates water supply from precipitation, modeled soil water storage, and solar radiation effects on water demand. I modeled soil water storage and drawdown using standard equations of plant water demand that are driven by incoming solar radiation (Dyer 2009). The data required include a digital elevation model (DEM), local climatic data, soil actual water holding capacity (AWC) grid, and solar radiation data (Table A3.1).

This approach calculates recharge for each grid cell based on climate data as well as topographic characteristics (Equation A3.1, Thornwaite-Mather, 1957). Precipitation data included daily data values from the weather station I constructed close to the study plots. Snowmelt is determined based on daily minimum, maximum, and average temperature but is not applicable within the time frame I analyzed and so was not included. I derived inflow from a flow direction grid, and interception followed the "bucket" model approach where the individual specifies the amount of interception by vegetation. I determined outflow based on soil type, land use, surface conditions, and prior runoff conditions (USGS, 2010).

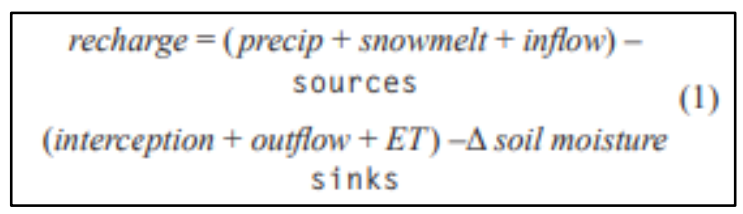

Equation A3.1: The Thornwaite-Mather equation for calculating soil recharge.

Model calculated components included potential evapotranspiration (PET), soil moisture storage, actual evapotranspiration (AET), and soil moisture deficit and surplus. I used the Turc 
method for PET estimation (Equation A3.2) within the water balance model, as performs well in relatively humid climates and takes into account topographically controlled variability between sites (Dyer, 2009), which have large impacts when investigating fine-scale water availability.

$$
\begin{aligned}
& \frac{\text { Humid climates (such as eastern U.S.) }}{} \\
& \qquad P E T=0.013 \times\left[\frac{T}{(T+15)}\right] \times(R+50)
\end{aligned}
$$

Equation A3.2: Turc Equation for estimation of Potential Evapotranspiration in $\mathrm{mm}$, where $\mathrm{T}$ is the average monthly temperature $\left({ }^{\circ} \mathrm{C}\right)$, and $\mathrm{R}$ is total monthly solar radiation $\left(\mathrm{cal} / \mathrm{cm}^{2}\right)$.

This method assessed potential patterns without consideration of current vegetation cover. The American Society of Civil Engineers (ASCE) found that the Turc Method slightly overestimated annual ET, but accurately accounted for the peak month and ranked it second

\begin{tabular}{|c|c|}
\hline $\begin{array}{cl}\text { Digital Elevation Model (DEM) } \\
-\quad 1 / 9 \text { arc-second } \\
-\quad \text { Used to derive necessary } \\
\text { parameters including aspect, slope, } \\
\text { solar radiation grids, and } \\
\text { topographic wetness index }\end{array}$ & $\begin{array}{l}\text { Produced by the United States Geologic } \\
\text { Survey (USGS) } \\
\text { The elevation is in feet } \\
\text { The coordinate system is UTM Zone } 17 \\
\text { Projection, horizontal datum NAD83 }\end{array}$ \\
\hline $\begin{array}{l}\text { Climate Data } \\
\begin{aligned} & \text { Monthly temperature and } \\
& \text { precipitation }\end{aligned}\end{array}$ & $\begin{array}{l}\text { Collected from EW weather station } \\
\text { Monthly averaged data for the } 2018 \text { growing } \\
\text { season at Elizabeth Woods from the Weather } \\
\text { Underground Morgantown Municipal Airport } \\
\text { Station. }\end{array}$ \\
\hline $\begin{aligned} \text { Available Water Capacity (AWC) } \\
-\quad \text { Raster format } \\
-\quad \text { Used a } 100 \mathrm{~cm} \text { soil depth, based on } \\
\text { the recommendation of Dyer } 2018,\end{aligned}$ & $\begin{array}{l}\text { Derived from the soil water capacity of } \\
\text { specific soil properties determined by the } \\
\text { United States Department of Agriculture's }\end{array}$ \\
\hline
\end{tabular}
behind the more complex Penman-Monteith approach (ASCE, 1990). 


\begin{tabular}{|l|l|}
\hline $\begin{array}{l}\text { which states that most of the tree } \\
\text { root activity is within the first } \\
\text { 100cm of soil. }\end{array}$ & $\begin{array}{l}\text { (USDA) Natural Resource Conservation } \\
\text { Service (NRCS). }\end{array}$ \\
\hline Solar Radiation Data & $\begin{array}{l}\text { Collected using Kipp \& Zoen Pyranometers } \\
\text { placed in an open field adjacent to the EW } \\
\text { TfE experiments. }\end{array}$ \\
\hline
\end{tabular}

Table A3.1: Data sources for running the water balance model

I applied a bi-weekly time-step to my water balance model to match the time step of my field measurements of crown architecture, canopy light environment, and soil moisture. At the treatment plots of the EW TfE experiments, where we were artificially reducing precipitation supply by excluding 50-90\% of the rain falling through the forest canopy, I reduced the recorded precipitation data appropriately before applying it in the water balance model. I executed the water balance model using conditionals in excel.

The treatment plots included slightly higher PET, combined with the 50-100\% exclusion of throughfall, that drove larger modeled differencess in the treatment plots. The MT experienced the largest deficit, $346 \mathrm{~mm}$, compared to the OT's $318 \mathrm{~mm}$. The OC and MC experienced deficits of $90 \mathrm{~mm}$ and $81 \mathrm{~mm}$, respectively (Figure A3.1). 


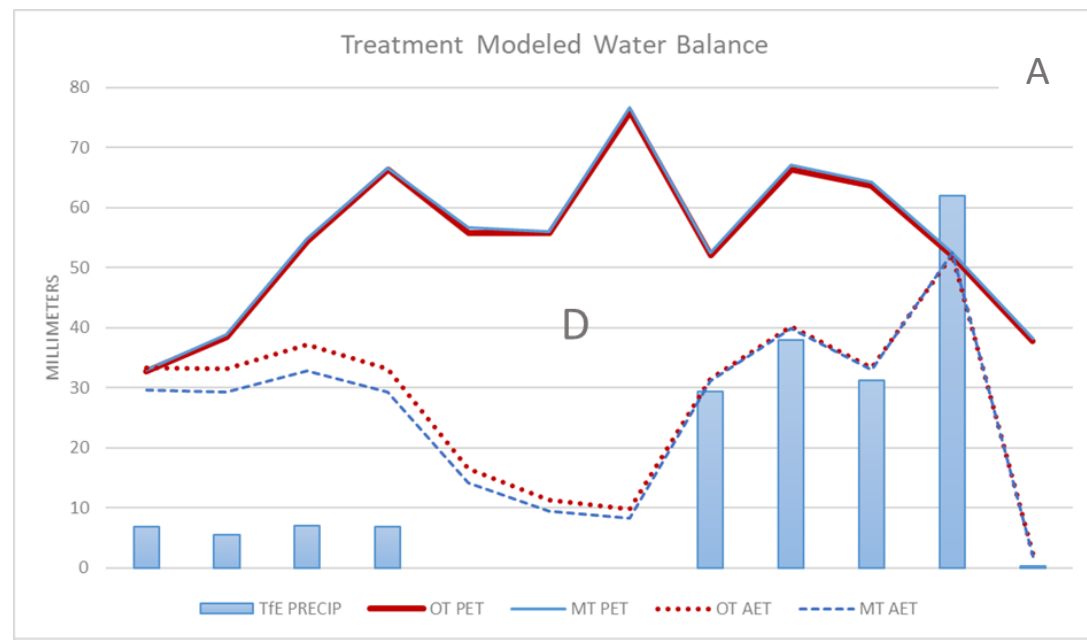

Control Modeled Water Balance

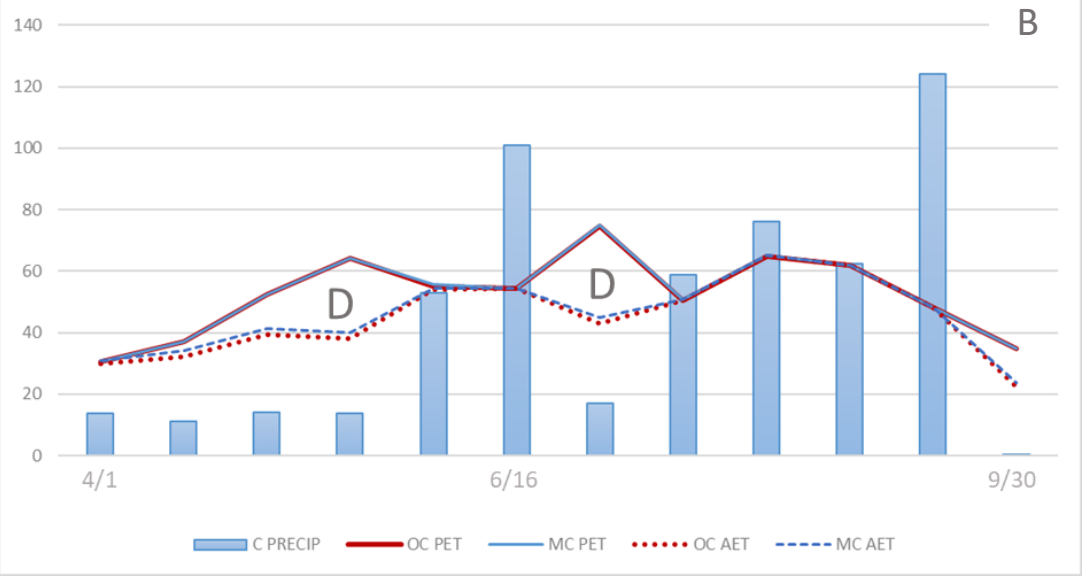

Figure 7: Molded AET and PET (demand) against precipitation (supply). Precipitation at the treatment plots $(A)$ have been reduced by $50-100 \%$ based on the status of the TfE while the control plots (B) include field measured values of precipitation. $A$ deficit occurs when PET exceeds AET and represent with a " $D$ ". 


\section{APPENDIX 4- Topographic Wetness Index:}

The topography is an important determining factor in soil moisture distribution, as well as impacting groundwater and surface flow. Studies have shown moisture estimations based on TWI (Sorenson et al., 2006). Understanding variability in soil moisture as a result of groundwater storage is crucial to understanding deficits within water balance models, which is dependent on the amount of water an area can store, as well as tree species response to changes in water availability. I used the topographic wetness index (TWI) developed by Beven and Kirkby (1979) for this study (Equation A4.1).

\section{$\mathrm{TWI}=\ln (a / \tan B)$}

Equation A4.1: The equation used to calculate TWI where $a$ is the local upslope area draining through a certain point per unit contour length, and $\tan B$ is the local slope.

I calculated the TWI using gridded elevation data and derived parameters. The slope is calculated per cell using the maximum change in value from surrounding cells. Flow accumulation is determined based on the numbers of cells flowing into each downslope cell. I used the raster grids created from the two above steps, in combination with Equation A4.1, to calculate the TWI for each raster cell within the study area. I averaged the pixel results within the extents of each study plot.

The TWI map exhibits spatial variability in the potential for saturation across the EW study site. Values varied from 0.3 to 10 . The mean TWI was highest in MT, followed by MC, OT, and OC with values of $2.57,2.53,2.03$, and 1.64 , respectively. Lowest values, presented in 
light blue, were recorded along ridges, as well as steeper slopes, while the highest values occurred at the toe of the slopes and flatter areas, represented in dark blue (Figure 1).

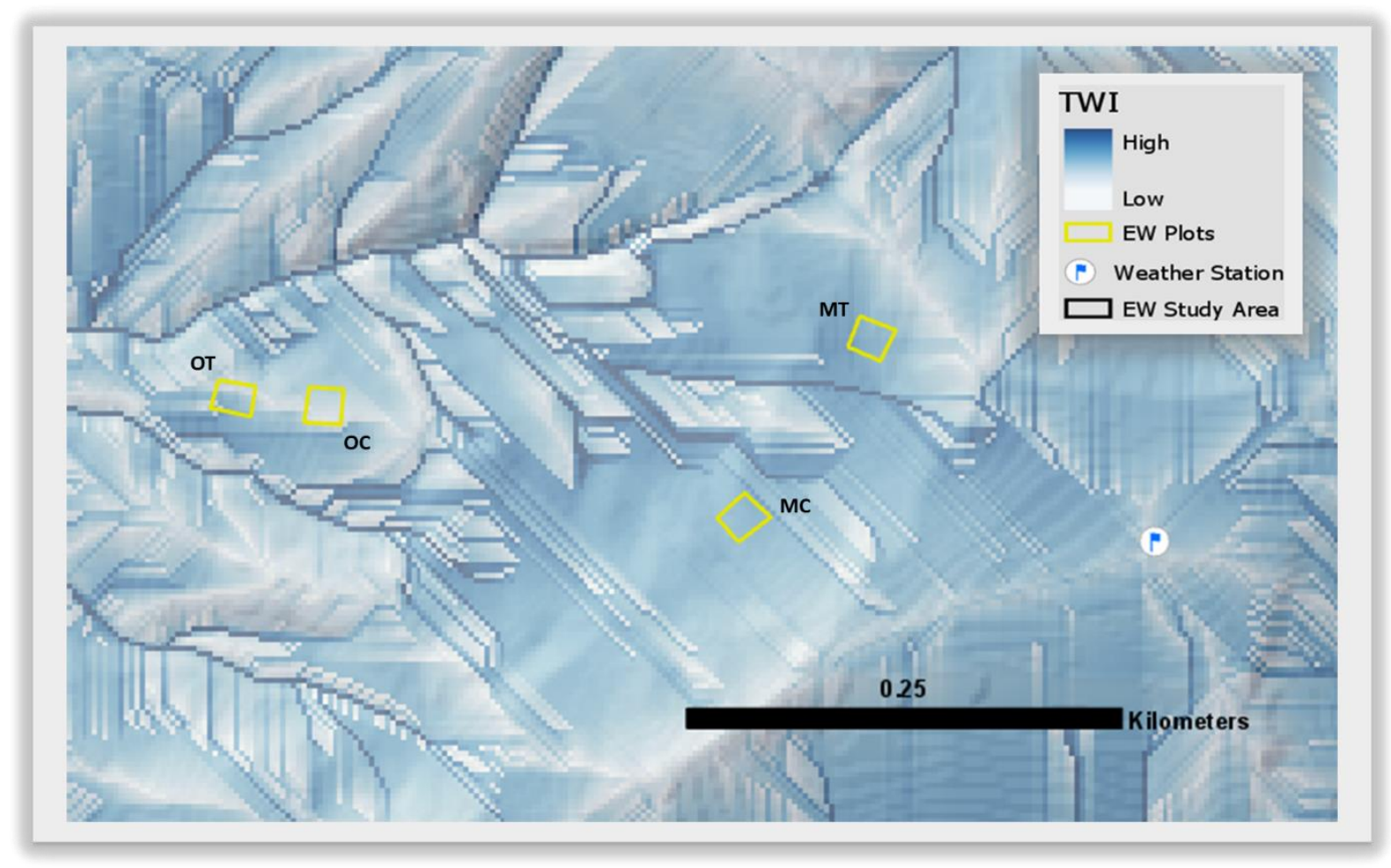

Figure 1: The topographic wetness index map to visualize the spatial variability in the potential for saturation. The higher the value, darker blue, the higher the potential for saturation which would impact soil moisture distribution throughout the study sites. 